\title{
Improved vaccine protection against retrovirus infection after co-administration of adenoviral vectors encoding viral antigens and type I interferon subtypes
}

Wibke Bayer ${ }^{1,2^{*}+}$, Ruth Lietz ${ }^{1 \dagger}$, Teona Ontikatze ${ }^{1,3}$, Lena Johrden ${ }^{1}$, Matthias Tenbusch', Ghulam Nabi ${ }^{1}$, Simone Schimmer ${ }^{2}$, Peter Groitt ${ }^{4,5}$, Hans Wolf ${ }^{4}$, Cassandra M Berry ${ }^{6}$, Klaus Überla ${ }^{1}$, Ulf Dittmer ${ }^{2+}$ and Oliver Wildner ${ }^{1,7+}$

\begin{abstract}
Background: Type I interferons (IFNs) exhibit direct antiviral effects, but also distinct immunomodulatory properties. In this study, we analyzed type I IFN subtypes for their effect on prophylactic adenovirus-based antiretroviral vaccination of mice against Friend retrovirus (FV) or HIV.

Results: Mice were vaccinated with adenoviral vectors encoding FV Env and Gag proteins alone or in combination with vectors encoding IFNa1, IFNa2, IFNa4, IFNa5, IFNa6, IFNa9 or IFN $\beta$. Only the co-administration of adenoviral vectors encoding IFN $\alpha 2$, IFN $\alpha 4$, IFN $\alpha 6$ and IFN $\alpha 9$ resulted in strongly improved immune protection of vaccinated mice from subsequent FV challenge infection with high control over FV-induced splenomegaly and reduced viral loads. The level of protection correlated with augmented virus-specific $C D 4^{+} T$ cell responses and enhanced antibody titers. Similar results were obtained when mice were vaccinated against HIV with adenoviral vectors encoding HIV Env and Gag-Pol in combination with various type I IFN encoding vectors. Here mainly CD4 ${ }^{+} \mathrm{T}$ cell responses were enhanced by IFNa subtypes.
\end{abstract}

Conclusions: Our results indicate that certain IFNa subtypes have the potential to improve the protective effect of adenovirus-based vaccines against retroviruses. This correlated with augmented virus-specific $\mathrm{CD} 4^{+} \mathrm{T}$ cell and antibody responses. Thus, co-expression of select type I IFNs may be a valuable tool for the development of antiretroviral vaccines.

Keywords: Friend virus, interferon alpha subtypes, human adenovirus vectors, human immunodeficiency virus, vaccine

\section{Background}

Type I interferons (IFNs) are major players of the innate immune response, which are produced by virus-infected cells and plasmacytoid dendritic cells. The murine genome comprises 14 type I IFN genes that encode structurally similar proteins of 161-167 amino acids in length. Type I

\footnotetext{
* Correspondence: wibke.bayer@uni-due.de

+ Contributed equally

'Department of Molecular and Medical Virology, Institute of Microbiology and Hygiene, Ruhr-University Bochum, Bldg. MA, Universitaetsstr. 150, D44801 Bochum, Germany

Full list of author information is available at the end of the article
}

IFN stimulation of a cell results in the expression of hundreds of IFN-regulated genes that mediate an anti-viral state of the cell [1]. In addition, type I IFNs also modulate adaptive immune responses by activating antigen-presenting cells, promoting natural killer cell cytotoxicity and enhancing the proliferation of $\mathrm{CD} 4^{+}$and $\mathrm{CD} 8^{+} \mathrm{T}$ cells [1]. All type I IFNs bind to and signal through the same receptor IFNAR (IFN $\alpha$ receptor) that consists of the two subunits IFNAR1 and IFNAR2; yet the anti-viral and immunomodulatory effects mediated by individual type I IFN subtypes vary considerably $[2,3]$. Distinct anti-viral effects of IFN subtypes were demonstrated in several 
infection models including murine cytomegalovirus, herpes simplex virus, influenza virus and Friend retrovirus infection [4-9].

While the antiviral functions of type I IFNs have been elucidated in detail, and IFN combination therapy is the standard of care in some viral infections like chronic hepatitis B and hepatitis C virus infection [10,11], their potential for modulating adaptive immune responses has only come into focus in recent years. Differing properties of distinct type I IFN subtypes have been described for immunotherapeutic approaches, but have not been systematically characterized for their effects on prophylactic vaccines. In the work presented here, we aimed to analyze type I IFN subtypes for their respective modulating effect on anti-retroviral immunization.

Even after 25 years of intensive research, an effective HIV vaccine remains elusive. Up to now, innumerable vaccine candidates have been developed and evaluated in preclinical models, but only three vaccines have been advanced into efficacy testing in large phase IIB or phase III clinical trials. The vaccination with a protein-based vaccine or adenoviral vectors, aiming exclusively at the induction of antibody responses or cytotoxic $\mathrm{T}$ cell responses, respectively, did not result in any protective effect $[12,13]$. Recently, the vaccination of a communityrisk group with a prime-boost combination of proteinand canarypox vector-based vaccines conferred moderate protection and instilled new hope in the field [14]. This data, together with results from animal models $[15,16]$, indicate that for the prevention of HIV infection, both cellular and humoral responses are necessary, and show that it is mandatory to develop means to selectively enhance these responses.

To analyze the protective effect of type I IFN subtypes on adenovirus-based immunization, we employed the Friend virus (FV) model. FV is an immunosuppressive retrovirus complex of the non-pathogenic Friend murine leukemia virus (F-MuLV) and the pathogenic, replicationdefective spleen focus forming virus (SFFV). FV infection of susceptible adult mice induces splenomegaly and erythroleukemia and takes a lethal course within a few weeks [17]. The FV infection is regarded as a very useful model for the analysis of immune responses to retroviral infections and for the identification of mechanisms of protection. It was shown that complete immune protection from FV infection requires complex immune responses involving antibodies and $\mathrm{CD}^{+}$as well as $\mathrm{CD}^{+} \mathrm{T}$ cells [15]. Previously, we demonstrated that the FV model is very suitable for the development and assessment of novel vectors and strategies for anti-retroviral vaccination. In this model, we showed the benefit of heterologous adenovirus-based prime-boost immunization, which resulted in better protection from FV challenge and enhanced neutralizing antibody responses than the repeated administration of one vector type [18]. Furthermore, we developed a new type of adenovirus-based expression-display vector that not only encodes a transgene, but also presents it on the adenovirus capsid and conferred strong protection from FV challenge infection, correlating with augmented $\mathrm{CD} 4^{+}$ $\mathrm{T}$ cell and anamnestic neutralizing antibody responses [19].

Using adenoviral vectors encoding F-MuLV Env and Gag proteins co-administered with vectors encoding murine type I IFN subtypes, we aimed to elucidate the effects of particular subtypes on vaccine-mediated protection in the FV model. To verify the results obtained in the FV model, we also performed immunizations of mice with adenoviral vectors expressing HIV Env and Gag-Pol proteins with co-administration of vectors encoding type I IFN subtypes.

\section{Results}

Enhanced FV immune protection after co-administration of adenoviral vectors expressing FV proteins and specific type I IFN subtypes

We generated E1-, E3-deleted Ad5-based vectors with wild-type or chimeric Ad5/35 fiber encoding murine type I IFN subtypes IFN $\alpha 1$, IFN $\alpha 2$, IFN $\alpha 4$, IFN $\alpha 5$, IFN $\alpha 6$, IFN $\alpha 9$ or IFN $\beta$. The identities of the IFN subtypes were verified by sequencing. and similar expression levels and biological functionality were demonstrated in an established bioassay [20] (data not shown). F-MuLV Env and Gag encoding adenoviral vectors were described previously [18].

Highly FV-susceptible CB6F1 mice were immunized with $1 \times 10^{9}$ viral particles (VP) each of F-MuLV Envand Gag-encoding Ad5 vectors and boosted with the same dose of Ad5F35 vectors three weeks later (see Additional file 1, Figure S1 for a schematic outline of the experiment). In contrast to our previous work in which we immunized with $5 \times 10^{9} \mathrm{VP}$ of each vector $\left(1 \times 10^{10}\right.$ VP total dose) $[18,19]$, this reduced-dose immunization was chosen because it induces only moderate protection on its own, enabling us to analyze the beneficial effect of vectored type I IFN co-administration on vaccine protection. Mice received the adenovirus-vectored F-MuLV antigens co-administered with vectors encoding the selected type I IFN subtypes described above; as a control, one group of mice received the adenoviral vectors encoding F-MuLV Env and Gag and were coadministered vectors encoding luciferase as an irrelevant transgene in order to administer equal amounts of adenoviral particles to all mice. Three weeks after the boost immunization the mice were challenged with FV and the spleen size as a surrogate marker for disease progression was monitored by abdominal palpation. While the immunization of mice with the reduced dose of F-MuLV Env- and Gag-encoding vectors alone did not result in 
significant protection against initial splenomegaly, coadministration of adenoviral vectors encoding IFN $\alpha 2$, IFN $\alpha 4$, IFN $\alpha 6$ or IFN $\alpha 9$, but not IFN $\alpha 1$, IFN $\alpha 5$ or IFN $\beta$, resulted in significant reduction of FV-induced splenomegaly $(P<0.05$; shown in Figure $1 \mathrm{~A}$ and $1 \mathrm{~B}$ for days 14 and 17 post-challenge (p.c.)). Improved protection after co-administration of the four IFN subtype vectors was confirmed when animals were sacrificed and spleen weights were measured on day 21 p.c. (Figure 1C). At this time point, the spleen weights of all vaccinated mice were significantly lower than of unvaccinated control mice demonstrating a moderate protective effect of the low-dose vaccination with F-MuLV Env- and Gag-encoding Ad5 and fiber-chimeric Ad5F35 vectors. However, protection against splenomegaly was significantly improved when mice had been co-administered vectors encoding IFN $\alpha 2$, IFN $\alpha 4$, IFN $\alpha 6$ or IFN $\alpha 9(P<0.05)$.

To ascertain that the observed effects of type I IFN coadministration were due to a modulation of the immune response to the vaccination and not to a direct antiviral effect of residual IFN expression, mice were administered type I IFN encoding vectors alone and challenged afterwards with FV according to the same scheme. Here, no differences in the control of FV-induced disease were observed (Figure 1D).

\section{Co-administration of specific type I IFN subtypes mediated improved control over viral replication in vaccinated mice}

To determine whether co-administration of type I IFNs resulted in improved control over virus replication after FV challenge, viral loads in plasma of animals immunized with F-MuLV Env and Gag encoding vectors with or without co-administration of IFN subtype encoding vectors were analyzed at 10 days after FV infection (Figure 2A). Vaccination with Env- and Gag-encoding vectors alone only slightly reduced acute viral loads but a significant reduction in viral titers was found in animals after coadministration of adenoviral vectors encoding the subtypes IFN $\alpha 4$, IFN $\alpha 6$ or IFN $\alpha 9(P<0.05)$. Some of the mice from these three groups even had viral loads below the detection limit of the assay. Co-administration of vectored IFN $\alpha 2$ also reduced the plasma viremia level of some mice compared to F-MuLV Env and Gag vaccinated mice but this reduction was not statistically significant.

In addition to acute viremia levels, numbers of infectious cells in the spleens of vaccinated mice were determined 21 days p.c. (Figure 2B). Co-administration of adenoviral vectors encoding IFN $\alpha 2$, IFN $\alpha 4$ or IFN $\alpha 6$ resulted in a significant reduction of spleen viral loads compared to both unvaccinated mice or mice vaccinated with Env- and Gag-encoding vectors alone $(P<0.05)$; the reduction in mean spleen viral loads was more than 1000-fold. After co-administration of vectors encoding IFN $\alpha 9$ or IFN $\beta$, the mean viral loads in spleens of mice were also reduced more than 100-fold compared to unvaccinated or Env- and Gag-vaccinated mice, but the differences did not reach statistical significance $(P>$ $0.05)$. No adjuvant effect on vaccine protection against $\mathrm{FV}$ was found for IFN $\alpha 1$ and IFN $\alpha 5$.

\section{IFN $\alpha 2,4,6$ and 9 co-expression enhanced vaccine- induced $\mathrm{CD}^{+} \mathrm{T}$ cell responses}

To elucidate the immunological mechanisms leading to improved protection after co-administration of specific type I IFN subtypes, we analyzed the virus-specific T cell response in mice vaccinated either with Env- and Gagencoding vectors alone or in combination with vectors encoding the four subtypes that improved protection (IFN $\alpha 2$, IFN $\alpha 4$, IFN $\alpha 6$ or IFN $\alpha 9$ ). Mice were vaccinated and challenged as described before and class I and II tetramer staining was performed at 3 days p.c. to quantify $\mathrm{T}$ cell responses (see Additional file 1, Figure S1 for a schematic outline of the experiment). For FV, only one H2$\mathrm{D}^{\mathrm{b}}$-restricted $\mathrm{CD} 8^{+} \mathrm{T}$ cell epitope, the GagL epitope [21], has been identified so far. However, this epitope is not processed in cells infected with the F-MuLV Gag-encoding adenoviral vector used in this study (data not shown). Therefore, it was not surprising that no FV-specific $\mathrm{CD}^{+}$ $\mathrm{T}$ cells were detected with class I tetramers in any of the vaccinated mice (data not shown). In contrast, shortly after FV challenge F-MuLV Env-specific CD $4^{+} \mathrm{T}$ cells could be quantified using MHC II tetramers presenting an F-MuLV gp70 epitope [22]. No tetramer ${ }^{+} \mathrm{CD}^{+}{ }^{+} \mathrm{T}$ cells were detectable in unvaccinated mice and in mice vaccinated with Env and Gag alone (Figure 3). In contrast, virus-specific $\mathrm{CD} 4^{+} \mathrm{T}$ cells were found in all mice that were co-administered vectors encoding IFN $\alpha 2$, IFN $\alpha 4$, IFN $\alpha 6$ or IFN $\alpha 9$ (with only one exception in the IFN $\alpha 9$ group; $P<0.05$; Figure 3A). Representative dot plots are shown in Figure 3B. Thus, these particular IFN subtypes significantly augmented $\mathrm{FV}$-specific $\mathrm{CD} 4^{+} \mathrm{T}$ cell responses.

\section{The role of T cells in IFN subtype mediated enhanced vaccine protection}

Previous work indicates that both $\mathrm{CD}^{+}$and $\mathrm{CD}^{+} \mathrm{T}$ cell responses contribute to vaccine protection against FV [15]. However, only FV-specific $\mathrm{CD}^{+}{ }^{+} \mathrm{T}$ cell responses were detected in the current vaccine study. To elucidate the impact of $\mathrm{CD}^{+}$and $\mathrm{CD}^{+} \mathrm{T}$ cells on vaccinemediated protection after co-administration of IFN subtypes, $\mathrm{T}$ cell depletion experiments were performed (see Additional file 1, Figure S1 for a schematic outline of the experiment). IFN $\alpha 4$ co-administration was selected to perform these experiments because it was the subtype 

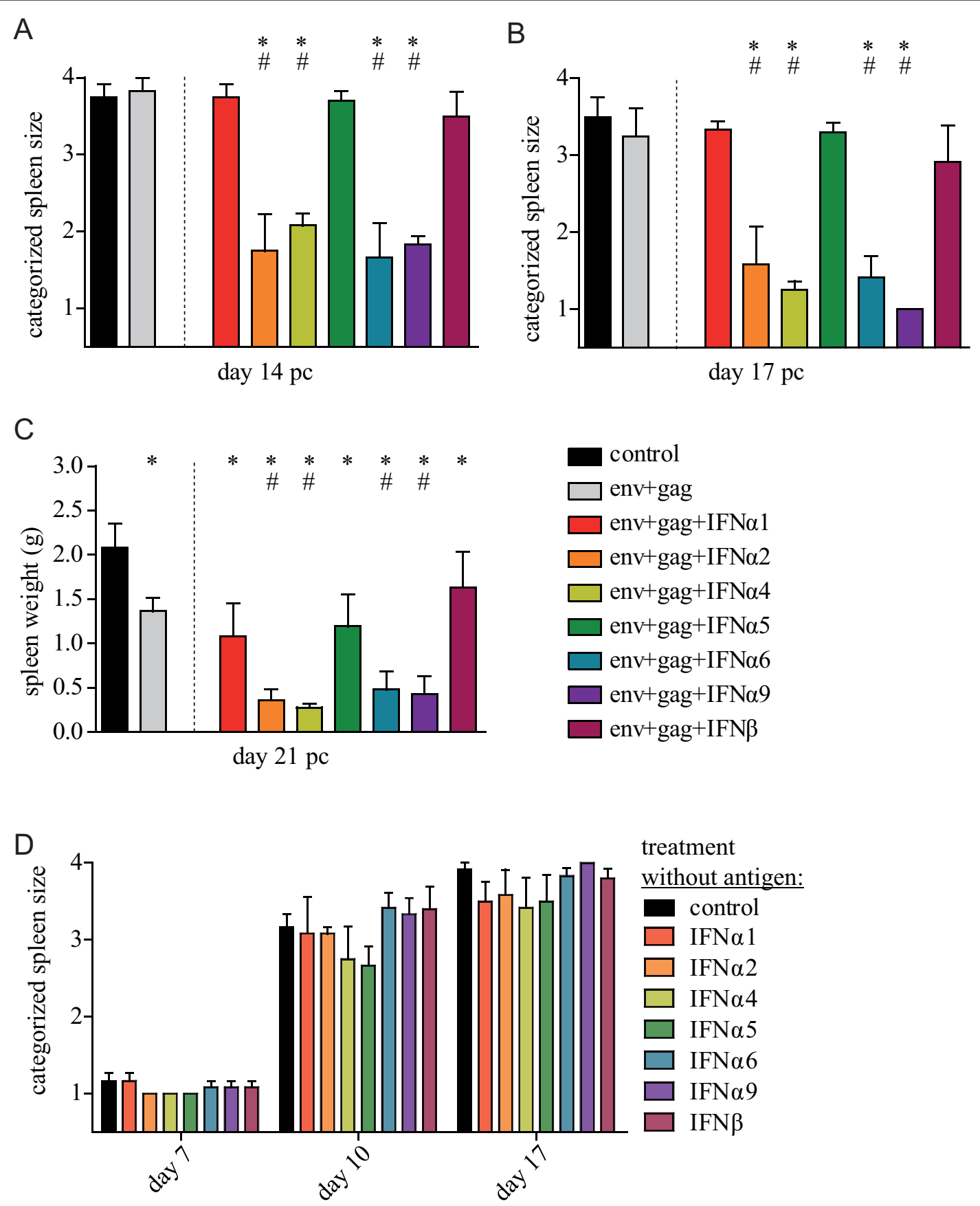

Figure $1 \mathrm{FV}$-induced splenomegaly in adenoviral vector immunized mice. CB6F1 mice were immunized with Ad5 and Ad5F35 based vectors encoding F-MuLV Env and Gag with or without co-administration of a specific vectored type I IFN subtype, as indicated. Ad5-based vectors were used for the prime immunization and Ad5F35 vectors for the boost immunization. Mice of the group "env+gag" received an equal amount of luciferase encoding adenoviral vectors instead of IFN encoding vectors to ensure that the total amount of particles used for immunization was the same in all groups. Three weeks after the boost immunization mice were challenged with FV. Disease progression was monitored by palpation of the spleen twice a week. The categorized spleens of six mice per group on day 14 p.c. (A) and day 17 p.c. (B) are shown (means + standard error of the means). On day 21 p.c. spleens were removed and weighed $(C)$. Statistically significant differences $(P<$ 0.05) compared to unvaccinated control mice $\left(^{*}\right)$ or mice vaccinated with Env- plus Gag-encoding vectors (\#) are indicated. Data are representative of two independent experiments. (D) CB6F1 mice were immunized twice with Ad5 and Ad5F35 based vectors encoding the indicated type I interferons alone and infected with FV three weeks after the second application of IFN vectors. The disease progression was monitored by twice-weekly palpations of the spleen, the graph shows the categorized spleen sizes (mean + standard error of the means) at the indicated time points after FV infection. 


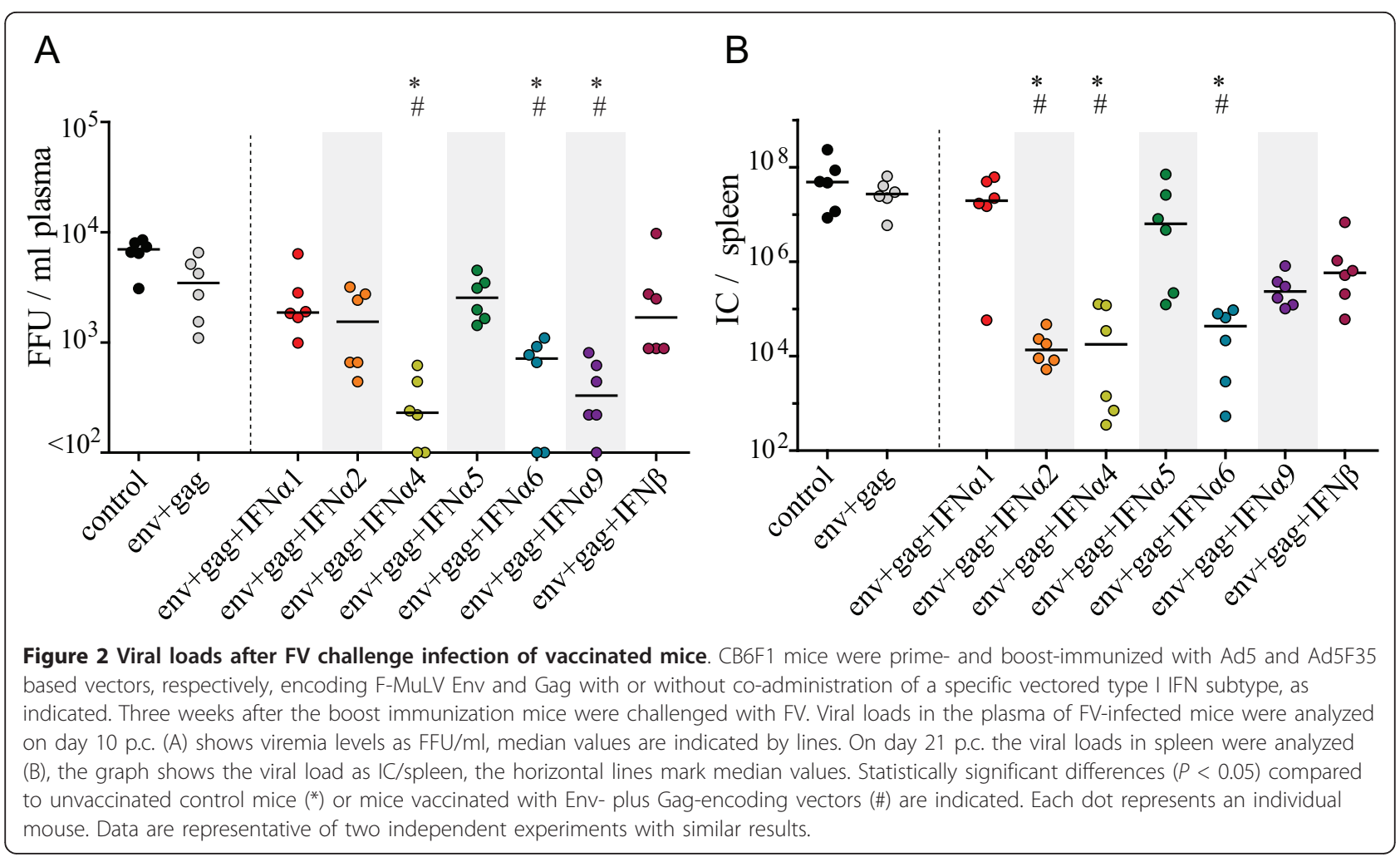

that mediated the strongest reduction in viral loads in vaccinated mice (Figure 2). Depletion of $\mathrm{CD}^{+} \mathrm{T}$ cells during the time of vaccination did not result in reduced protection in mice inoculated with vectors encoding Envand Gag and IFN $\alpha 4$ (Figure 4). This indicates that in the absence of $\mathrm{CD}^{+} \mathrm{T}$ cells reactive to the immunodominant GagL epitope, also no $\mathrm{CD}^{+} \mathrm{T}$ cells of other, unknown specificity played a major role in vaccinemediated protection. However, depletion of $\mathrm{CD}^{+}{ }^{+} \mathrm{T}$ cells had a profound effect on protection. The depletion abolished the protective effect of the Env/Gag/IFN $\alpha 4$ vaccine completely as indicated by severe splenomegaly (Figure 4A) and high plasma (Figure 4B) and spleen (Figure 4C) viral loads in these mice. Thus, the $\mathrm{CD} 4^{+} \mathrm{T}$ cell response in Env and Gag vaccinated mice, which was augmented by co-administration of IFNa4 (Figure 3) was absolutely critical for vaccine protection.

To analyze the kinetics of the improved $\mathrm{CD}^{+} \mathrm{T}$ cell response, we immunized mice once with Ad5.env+gag or Ad5.env+gag+IFN $\alpha 4$ and analyzed activation of $\mathrm{CD}_{4}^{+}$ $\mathrm{T}$ cells in the draining lymph nodes at 3,7 or 10 days after immunization. While we did not see any difference between mice from the two groups in the percentage of activated CD4+ T cells with effector phenotype (CD43 ${ }^{+}$ CD $44^{+} \mathrm{CD}^{+} 2 \mathrm{~L}^{-} \mathrm{CD} 4{ }^{+} \mathrm{T}$ cells; data not shown), at 10 days after immunization the mean percentage of activated $\mathrm{CD} 43^{+} \mathrm{CD} 44^{+} \mathrm{CD} 4^{+} \mathrm{T}$ cells with a entral memory phenotype $\left(\mathrm{CCR}^{+} \mathrm{CD}^{2} 2 \mathrm{~L}^{+}\right)$was increased in mice co- administered IFNa4 (Figure 4D), suggesting a role of IFNa4 in $\mathrm{CD}^{+} \mathrm{T}$ cell memory formation.

\section{Enhanced antibody titers after co-administration of specific type I IFN subtypes}

Virus-specific antibodies have been shown to play an important role in vaccine protection against FV infection [15,23]. Therefore, we analyzed the humoral immune responses to vaccination at 18 days after the boost immunization as well as 10 days p.c. After Envand Gag-vaccination, only two out of six mice had developed detectable F-MuLV-binding antibodies after the boost immunization (Figure 5A), whereas all mice that had received vectors encoding IFN $\alpha 2$, IFN $\alpha 4$, IFN $\alpha 6$ or IFN $\alpha 9$ had significantly higher mean FMuLV-binding antibody titers $(P<0.05)$, with the highest titers found in mice that had been co-administered vectors encoding IFN 22 and IFN $\alpha$ 9. FV neutralizing antibodies were not detected in any of the vaccinated mice (data not shown). However, at ten days after FV challenge, most vaccinated animals showed low titers of F-MuLV-neutralizing antibodies (Figure 5B), which were only increased after co-administration of IFNa2- and IFNa4-encoding vectors compared to the group of Env- and Gag-immunized mice. While this increase was statistically significant for IFN 4 4 $(P<0.05$; Figure 5B), it did not reach statistical significance for IFN 2 . 


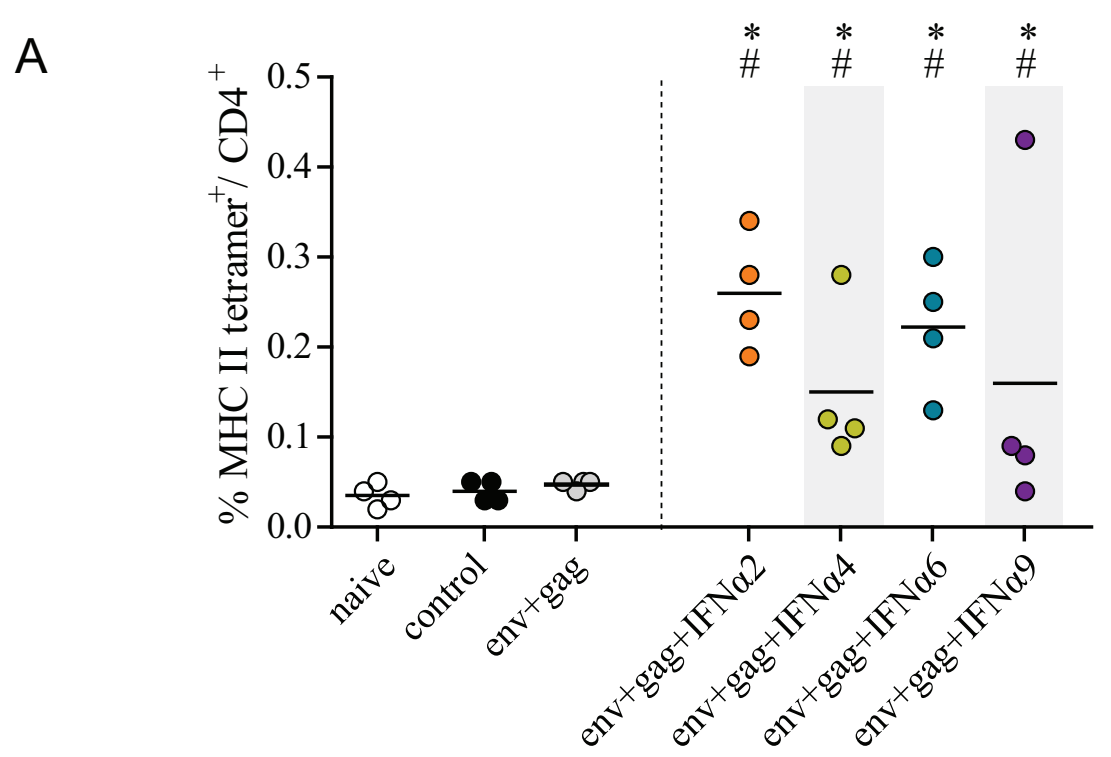

B
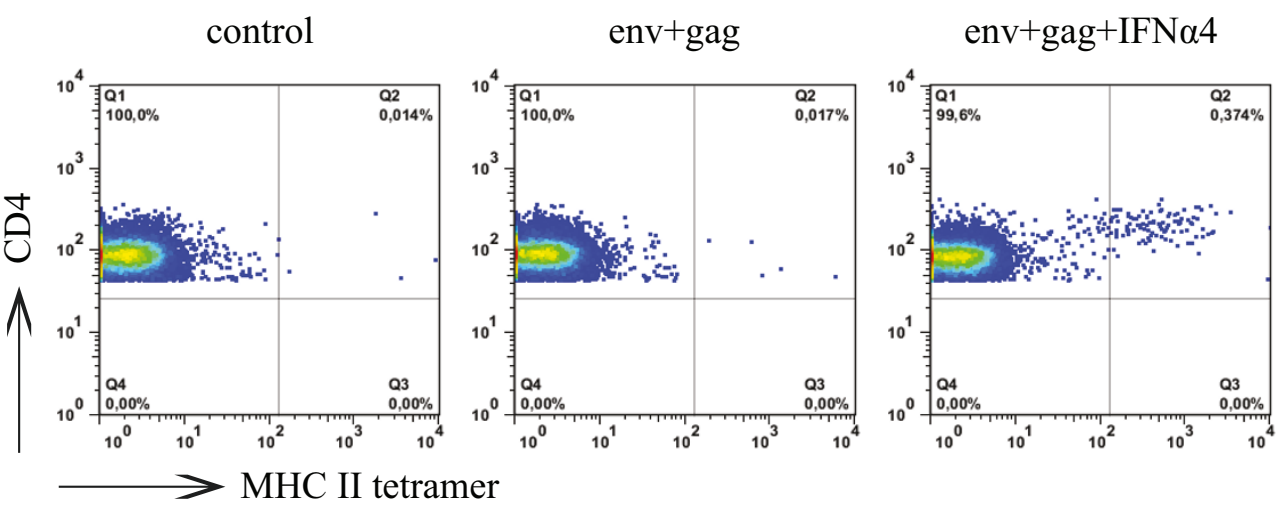

Figure 3 Vaccine-induced F-MuLV Env-specific $\mathrm{CD}^{+} \mathbf{T}$ cell responses. CB6F1 mice were prime- and boost-immunized with Ad5 and Ad5F35 based vectors, respectively, encoding F-MuLV Env and Gag with or without co-administration of a specific vectored type I IFN subtype, as indicated. Three weeks after the boost immunization mice were challenged with FV and the F-MuLV Env-specific CD4 ${ }^{+} \mathrm{T}$ cell response was analyzed 3 days p.c. by staining with MHC II tetramers presenting an F-MuLV Env gp70-derived epitope. (A) The graph shows the percentage of MHC II tetramer ${ }^{+} \mathrm{CD}^{+} \mathrm{T}$ cells, the line designates the mean value. Statistically significant differences $(P<0.05)$ compared to unvaccinated control mice $\left(^{*}\right)$ or mice vaccinated with Env- plus Gag-encoding vectors (\#) are indicated. Each dot represents an individual mouse. Data are representative of two independent experiments with similar results. (B) Representative dot plots from an unvaccinated mouse and mice vaccinated with env+gag or env+gag+IFNa 4 are shown.

\section{Cellular immune responses to an adenovirus-based HIV vaccine were improved by co-administration of select type I IFN subtypes}

To determine whether the adjuvant effect of type I IFN subtypes also applied to vaccination against HIV, we analyzed immune responses to an HIV vaccine in mice using adenoviral vectors expressing HIV Env and Gag-Pol alone or in combination with vectors encoding IFNa2, IFN $\alpha 4$, IFN $\alpha 6$ or IFN $\alpha$ 9. For the analysis of cellular immune responses, BALB/c mice were immunized once with Ad5-based vectors and spleens were removed two weeks later (see Additional file 1, Figure S1 for a schematic outline of the experiment) to determine cytokine production by $\mathrm{CD}^{+}$and $\mathrm{CD}^{+} \mathrm{T}$ cells after in vitro restimulation with HIV Gag derived peptides that have been described before to be relevant T cell epitopes in BALB/c mice $[24,25]$.

A significant induction of $\mathrm{CD}^{+}{ }^{+} \mathrm{T}$ cells producing IFN $\gamma$, TNF $\alpha$ or IL- 2 by the HIV antigen encoding adenovirusbased vaccine was observed in all mice $(P<0.05$; Figure 6 A-C). Compared to Env- and Gag-Pol-immunization alone, significantly higher mean percentages of HIV Gagspecific CD4 ${ }^{+} \mathrm{T}$ cells producing IL-2 (only for IFNa2) or TNF $\alpha$ after restimulation were found in mice that had been co-administered vectors encoding IFN 2 , IFN 44 or IFNa9 $(P<0.05)$. In contrast, IFNa 6 had no effect on 

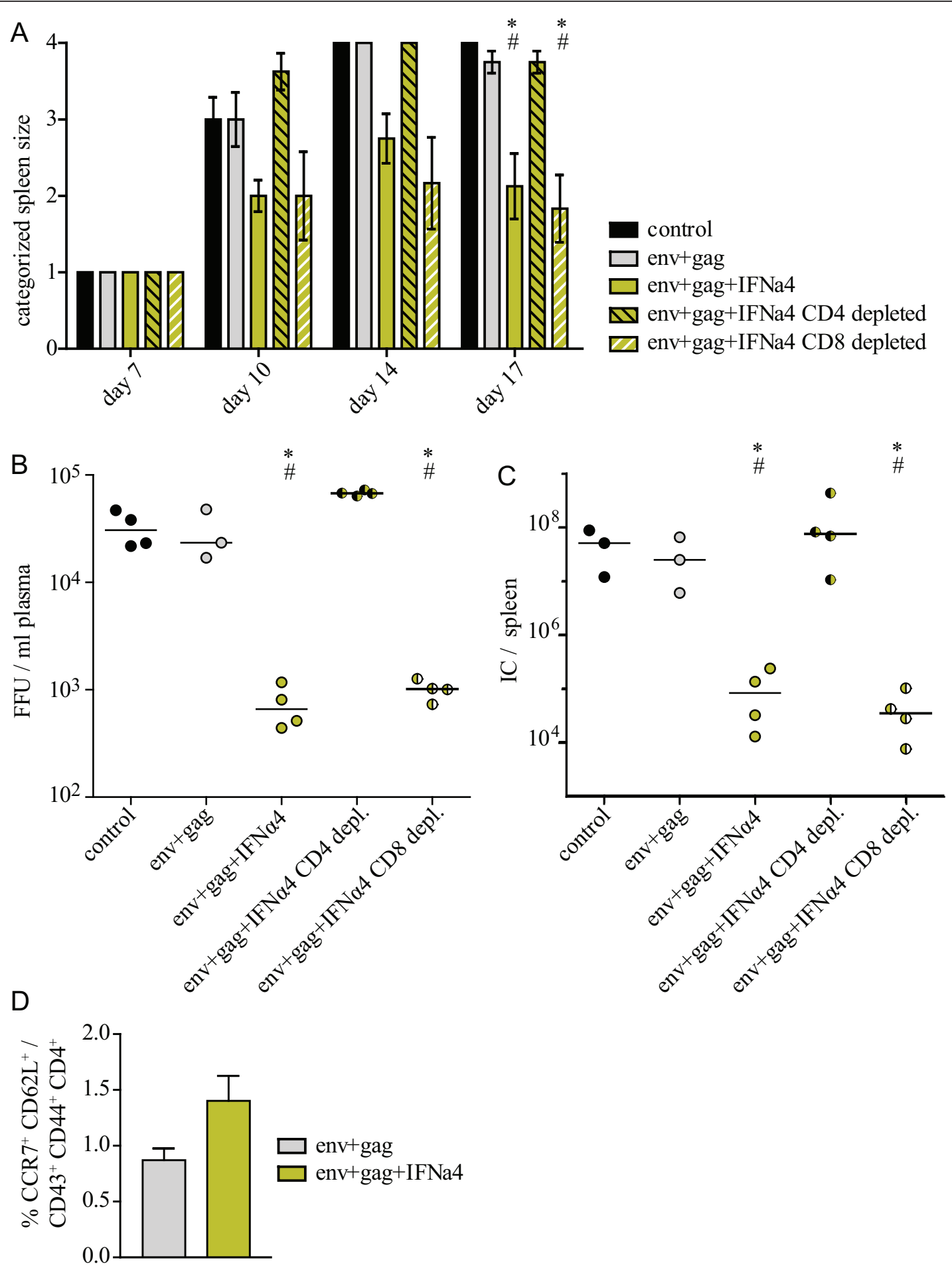

Figure 4 Depletion of $\mathrm{CD}^{+}$and $\mathrm{CD8}^{+}$T cells during vaccination. CB6F1 mice were vaccinated with adenoviral vectors encoding F-MuLV Env and Gag with or without co-administration of vectored IFNa 4 as described before. On day $-3,-1,+1,+3$, and +5 of vaccination, mice were injected i.p. with antibodies against CD4 or CD8 to deplete the respective T cell subset. After FV challenge infection, spleens were palpated twice a week to monitor disease progression (A). Viral loads in plasma were determined on day 10 p.c. (B), viral loads in spleen were analyzed on day 21 p.c. (C). For the analysis of T cell induction, mice were immunized once with the indicated vectors and the expression of CD43, CD44, CD62L and CCR7 on CD4+ T cells in the draining lymph nodes was analyzed 10 days after immunization (D). The graphs show data of four mice per group. Statistically significant differences $(P<0.05)$ compared to unvaccinated control mice $\left.{ }^{*}\right)$ or mice vaccinated with Env- plus Gagencoding vectors (\#) are indicated. 


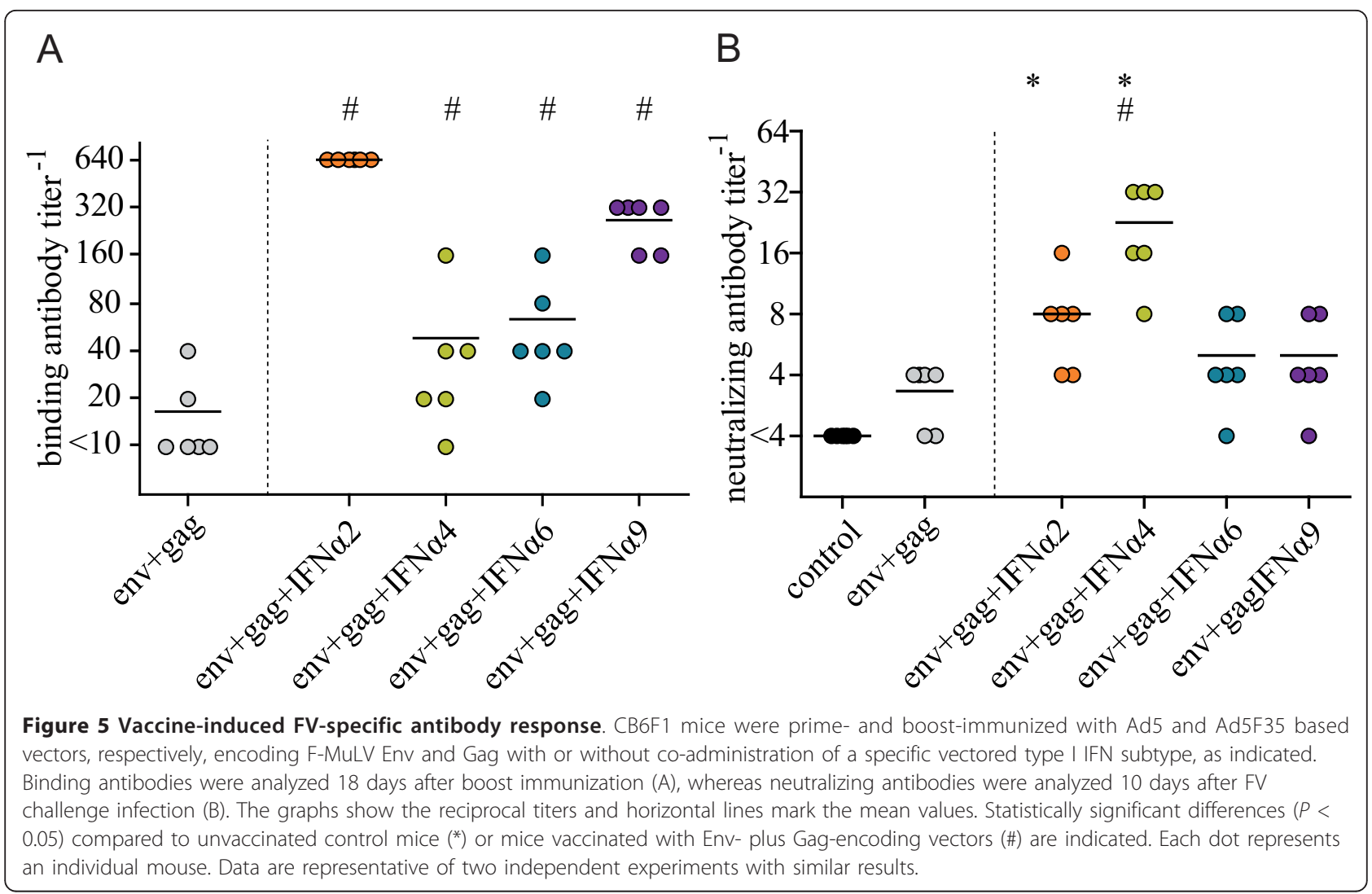

HIV Gag-specific $\mathrm{CD} 4^{+} \mathrm{T}$ cell responses. In addition, the IFN $\gamma$ expression by $\mathrm{CD} 4^{+} \mathrm{T}$ cells was not changed by any of the four type I IFN subtypes. Similar results were also obtained when mice were immunized twice with a prime boost immunization protocol using Ad5-based vectors for priming and Ad5F35-based vectors for boosting, resembling the FV experiments. Again IFN $\alpha 2$, IFN $\alpha 4$ or IFN $\alpha 9$ enhanced $\mathrm{CD} 4^{+} \mathrm{T}$ cells responses but in these experiments the differences between the groups were not as pronounced as after only one vaccination (data not shown).

Similar to the $\mathrm{CD}^{+}{ }^{+} \mathrm{T}$ cell response, the HIV Env- and Gag-Pol-immunization induced cytokine producing $\mathrm{CD} 8^{+}$ $\mathrm{T}$ cells, which responded specifically to restimulation with Gag-derived peptides (Figure $6 \mathrm{D}-\mathrm{E}$ ). The mean percentages of cytokine producing $\mathrm{CD}^{+} \mathrm{T}$ cells were higher than those for $\mathrm{CD} 4^{+} \mathrm{T}$ cells. However, after co-delivery of IFN $\alpha 2$, IFN $\alpha 4$ or IFN $\alpha 6$ only slightly enhanced mean percentages of IL-2 producing HIV Gag-specific $\mathrm{CD} 8^{+} \mathrm{T}$ cells were detected than in Env- and Gag-Pol-immunized mice and the difference did not reach statistical significance. Expression levels of TNF $\alpha$ and IFN $\gamma$ were comparable in all immunized mice irrespective of IFN co-administration, with very high percentages of IFN $\gamma$-producing $\mathrm{CD} 8^{+} \mathrm{T}$ cells in all groups. Similar results were obtained when $\mathrm{CD}^{+} \mathrm{T}$ cells were restimulated with an Env-derived epitope peptide (data not shown).
These data underline the impact of specific type I IFNs on vaccine-induced $C D 4^{+} T$ cell responses, whereas only little effect on the $\mathrm{CD}^{+} \mathrm{T}$ cell response could be demonstrated.

\section{Discussion}

Type I IFN subtypes have distinct immunomodulatory and antiviral properties, which implies that they have different potentials for immunotherapeutic applications [4-9] and emphasizes the need for careful subtype selection for infectious disease treatment. Type I IFNs have also been used to improve the efficacy of experimental vaccines including protein [26], DNA [8,27-30] and viral vector vaccines [31-33], but a systematic approach to study the adjuvant efficacy of different IFN subtypes has not been undertaken so far. In this study, we analyzed seven adenovirus-vectored type I IFN subtypes for their effect on an adenoviral vectorbased anti-retroviral vaccination. As expected, the effect on vaccine efficacy of the IFN subtypes differed greatly. While the co-administration of adenoviral vectors encoding IFN $\alpha 2$, IFN $\alpha 4$, IFN $\alpha 6$ and IFN $\alpha 9$ led to improved control over FV-induced disease and strongly reduced viral loads, no or only slight effects were observed after co-administration of the subtypes IFN $\alpha 1$, IFN $\alpha 5$ and IFN $\beta$. All four IFN subtypes that improved vaccine protection enhanced virusspecific $\mathrm{CD} 4^{+} \mathrm{T}$ cell and antibody responses. 


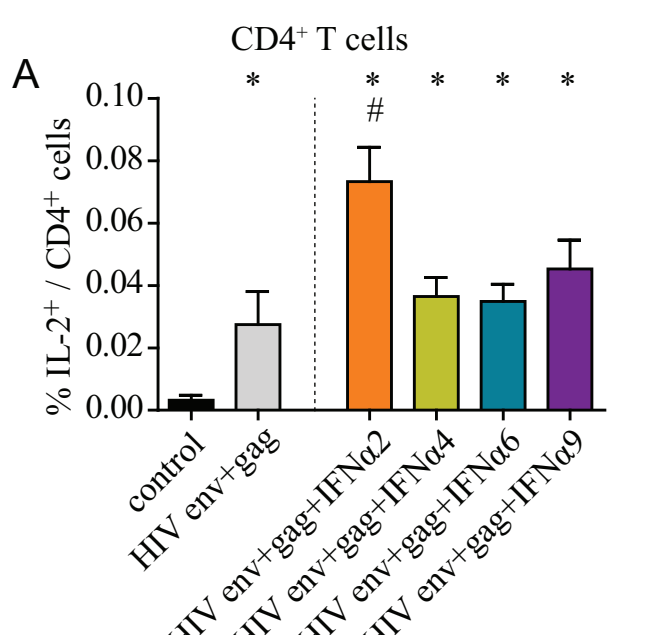

B

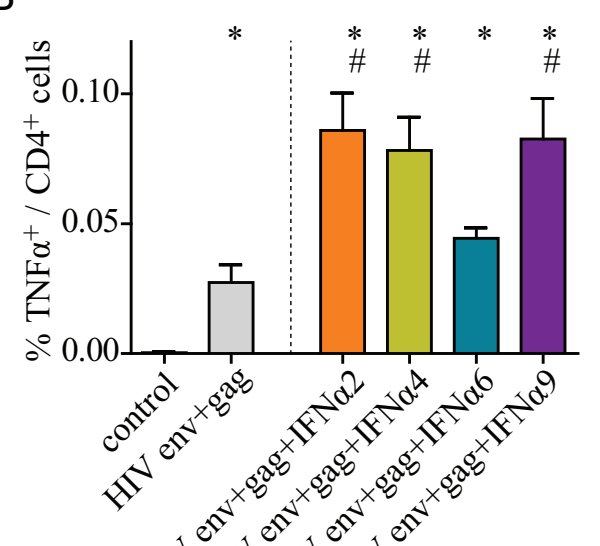

से से से

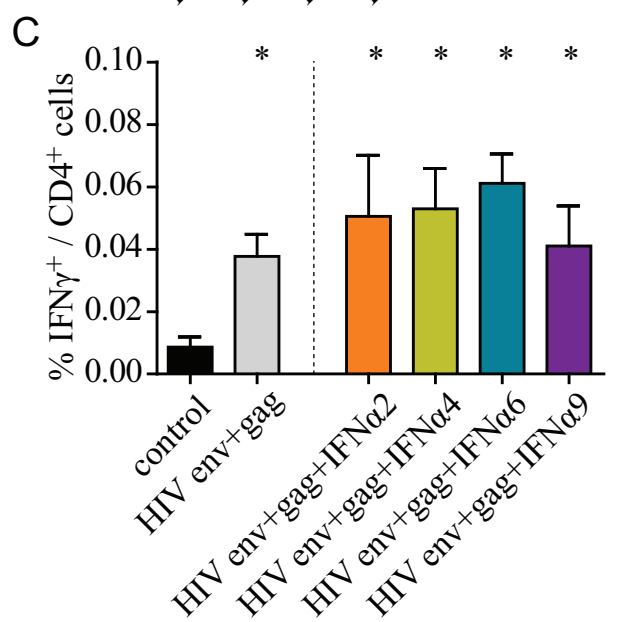

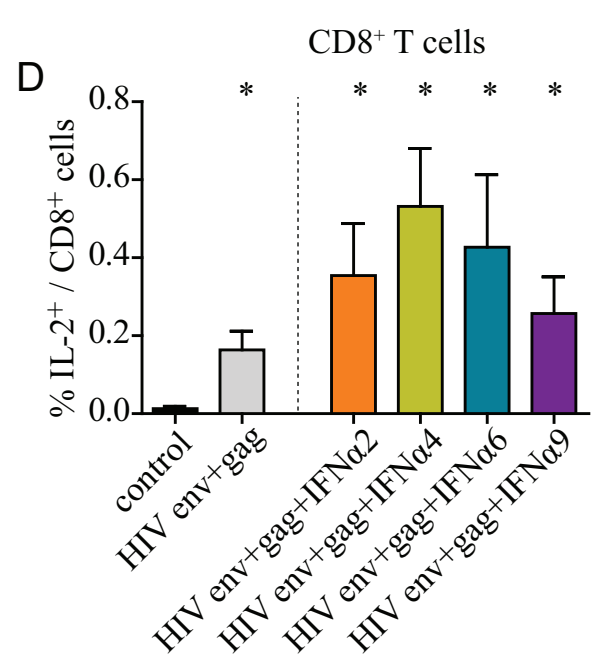

$\mathrm{E}$

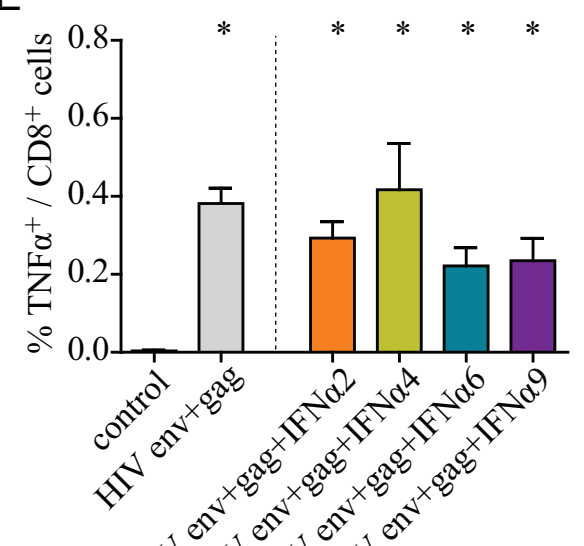

$\mathrm{F}$

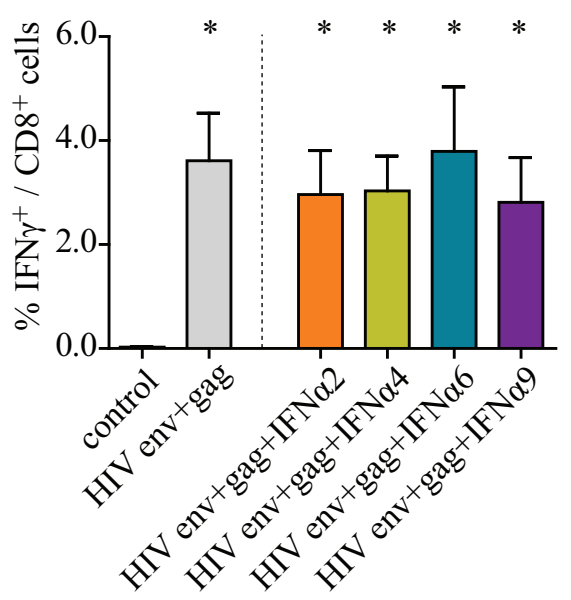

Figure 6 HIV Env- and Gag-specific T cell responses after adenovirus-based vaccination. Two weeks after a single immunization with HIV Env and Gag encoding Ad5-based vectors in combination with Ad5 vectors encoding specific type I IFN subtypes, spleens were removed and after in vitro restimulation of spleen cells with HIV Gag-derived peptides the expression of IL-2, TNF- $\alpha$ and IFN- $\gamma$ by CD4 $4^{+}$(A-C) and CD8 $8^{+}$T cells (D-F) was analyzed. The graphs show mean percentages with standard error of the means for six mice per group. Statistically significant differences $(P<0.05)$ compared to unvaccinated control mice $\left.{ }^{*}\right)$ or mice vaccinated with Env- plus Gag-encoding vectors (\#) are indicated. Data were acquired in two independent experiments. 
The importance of the FV-specific $\mathrm{CD}^{+} \mathrm{T}$ cell response for vaccine protection was emphasized by a depletion experiment, in which vaccine-mediated protection was completely abolished when $\mathrm{CD}^{+} \mathrm{T}$ cells were depleted around the time point of vaccination. The kinetic analysis of the early activation of $\mathrm{B}$ cells and $\mathrm{CD}^{+}{ }^{+} \mathrm{T}$ cells after vaccination suggests that co-administration of IFN $\alpha 4$ might influence the $\mathrm{CD}^{+}$memory $\mathrm{T}$ cell formation, whereas no differences in overall activation of $\mathrm{CD}^{+}$or $\mathrm{CD}^{+} \mathrm{T}$ cells with effector phenotype or $\mathrm{B}$ cells was found (data not shown). An improved central memory $\mathrm{CD}_{4}{ }^{+} \mathrm{T}$ cell response might be critical for enhanced virus-specific cellular and humoral recall responses after virus challenge, as similar findings have been reported for FV infected mice [34].

The importance of $\mathrm{CD}^{+} \mathrm{T}$ cell responses for vaccineinduced protection from FV infection has been demonstrated before in mice vaccinated with an attenuated FMuLV and in vaccination studies with peptides containing $\mathrm{CD}^{+} \mathrm{T}$ cell epitopes $[35,36]$. In the attenuated vaccine experiments it was suggested that the $\mathrm{CD} 4^{+} \mathrm{T}$ cells mainly provided help for $\mathrm{B}$ cells and $\mathrm{CD}^{+} \mathrm{T}$ cells rather than exerting direct effector functions [15,37]. It was also shown in FV infected mice that the $\mathrm{CD}_{4}^{+} \mathrm{T}$ cell response is crucial for efficient induction of virus-specific antibodies [34]. These findings correspond well with our data, as we observed a correlation of $\mathrm{CD} 4^{+} \mathrm{T}$ cell induction and antibody responses in mice vaccinated against FV.

The important role of antibodies for protection from FV infection has also been demonstrated before [15,37]. It is noteworthy that in our challenge experiment, mice that were co-administered IFN $\alpha 4$ had the strongest anamnestic neutralizing antibody response and also the lowest acute viral load in plasma. While this antibody response might be influenced by the augmented $C D 4^{+} \mathrm{T}$ cell response, a direct effect of the type I IFNs on antibody induction is conceivable, as it has been shown that type I IFNs enhance primary antibody responses, promote isotype switching and can increase B cell survival [38,39].

In mice immunized with peptides representing $\mathrm{CD} 4^{+} \mathrm{T}$ cell epitopes, improved maturation of neutralizing antibodies [36], but also direct effector function of vaccineinduced $\mathrm{CD}_{4}^{+} \mathrm{T}$ cells have been reported [35]. Also in FV-infected mice, direct anti-viral effects of $\mathrm{CD} 4^{+} \mathrm{T}$ cells have been documented $[34,40,41]$, which were found to be mediated by inhibition of virus replication by production of IFN $\gamma$ and by MHC class II restricted cytotoxicity [40]. Type I IFNs can promote expansion of CD4 ${ }^{+} \mathrm{T}$ cells either indirectly through effects on antigen-presenting cells [42] or through direct action $[43,44]$. The current findings suggest that co-delivery of certain type I IFN subtypes in our vaccine may facilitate the induction of direct anti-viral CD4 ${ }^{+} \mathrm{T}$ cell activity. This is supported by the fact that we see a strong correlation of high control of FV-induced disease with the augmented $\mathrm{CD} 4^{+} \mathrm{T}$ cell response, whereas the levels of binding and neutralizing antibodies are not equally increased by co-administration of all analyzed IFNs, indicating a direct function of virusspecific $\mathrm{CD}^{+} \mathrm{T}$ cells.

In the FV model, the only known $\mathrm{CD}^{+} \mathrm{T}$ cell epitope is located in the leader region of the Gag protein [21], but after vaccination with adenoviral vectors encoding FMuLV Gag, no immune response against this epitope was detected because the epitope peptide was obviously not processed. However, the vaccination with adenoviral vectors very likely induced $\mathrm{CD}^{+} \mathrm{T}$ cell responses of up to now unknown specificity as activated $\mathrm{CD}^{+} \mathrm{T}$ cells with effector phenotype were detected after immunization (data not shown). This is in line with previous reports that after vaccination with vaccinia viruses encoding different F-MuLV Gag constructs also regions other than the leader can induce protective $\mathrm{CD}^{+} \mathrm{T}$ cell immune responses [45]. However, our $\mathrm{CD}^{+} \mathrm{T}$ cell depletion experiment did not result in reduced protection, suggesting that $\mathrm{CD}^{+} \mathrm{T}$ cell responses against other epitopes did not play a critical role for the improved protection after co-administration of type I IFNs. Our data from vaccination of mice against HIV proteins also showed only minor effects of type I IFNs on $\mathrm{CD}^{+} \mathrm{T}$ cell responses, suggesting that these cytokines may not be very efficient to enhance adenovirus-based vaccine induced $\mathrm{CD}^{+} \mathrm{T}$ cell responses.

Some of the IFN subtypes used in this study have been evaluated before to enhance immune responses to protein, plasmid or viral vector based vaccines. The data imply that the adjuvant potential of IFN subtypes may vary depending on the type of vaccine. For DNA and protein-based vaccines against model antigens or virus infections, most efforts to improve vaccine efficacy by co-administration of type I IFNs resulted in improved antibody and $\mathrm{CD} 8^{+} \mathrm{T}$ cell responses that mediated enhanced protection [8,26-30]. The effect of type I IFN co-expression in virusvector based vaccines, however, seems to depend on the vector-type. Immune responses, but not protection, induced by a rabies virus based vaccine against HIV could be improved by co-expression of IFN $\beta$ [32]. The protective effect of a vaccinia virus-vectored vaccine against influenza, on the other hand, was not improved by IFN $\beta$ or IFNa4 co-administration [31]. Interestingly, none of the above cited publications reports an enhanced induction of $\mathrm{CD}^{+}{ }^{+} \mathrm{T}$ cells, while we found strongly augmented $\mathrm{CD} 4^{+} \mathrm{T}$ cell responses that correlated well with the observed improved protection against systemic FV challenge infection conferred by codaministration of specific type I IFN subtypes with the vaccine.

It seems plausible that virus-based vectors are more immunogenic by themselves and thus effects of cytokine 
coexpression are harder to achieve than with DNA or protein vaccines. In our current vaccination study, the finding that only IFN $\alpha 2$, IFN $\alpha 4$, IFN $\alpha 6$ and IFN $\alpha 9$, but not IFN $\alpha 1$, IFN $\alpha 5$ and IFN $\beta$, had an adjuvant effect on the adenovirus-based vaccine may also be related to the immunogenicity of the vector itself. In fact, the ineffective IFN subtypes were those that were expressed at the highest levels in Ad-infected DCs (see Additional file 2, Figure S2), which is in accordance with an earlier report showing that the adenovirus-induced type I IFN response was predominantly comprised of IFN $\alpha 1$, IFN $\alpha 5$ and IFN $\beta$ [46]. While additional expression of these IFN subtypes from the vaccine vectors did not enhance immunogenicity, broadening the IFN profile by expressing other IFN subtypes seems to be more effective. It has been established that, while all type I IFNs signal through the same receptor, the IFN subtypes bind this receptor with different affinities $[47,48]$. These differences in receptor binding can result in different downstream signaling events and distinct induction of interferon stimulated genes. Thus, the tested IFN subtypes may have induced different activation pattern in vaccine-primed immune cells, which might be an underlying mechanism for their distinct adjuvant effects.

The homology between murine and human type I interferons is rather low with about $70-75 \%$ at the nucleotide level [49], so a direct translation of our findings into HIV vaccine development for humans is difficult. However, also human type I interferon subtypes exhibit distinct immunological functions [47], so that our main findings that different IFN subtypes have distinct potencies as vaccine adjuvants should hold true for human IFN subtypes as well. Thus, human IFN subtypes should be tested when developing HIV prototype vaccines.

We demonstrated that the protective effect of low-dose immunization against retroviruses with adenoviral vectors could be highly improved by co-administration of specific vectored type I IFN subtypes, which induced strong $\mathrm{CD}^{+} \mathrm{T}$ cell responses and enhanced binding antibody titers. This shows that careful manipulation of the cytokine milieu can result in impressive advancement in vaccine efficacy and suggests that IFN subtypes may be useful tools to improve immune responses to adenovirusbased vaccines.

\section{Conclusions}

This study examines the adjuvant effect of distinct type I IFN subtypes on an adenoviral vector-based anti-retroviral vaccine. In the Friend virus model, the co-delivery of IFN $\alpha 2$, IFN $\alpha 4$, IFN $\alpha 6$ and IFN $\alpha 9$ together with viral antigens by an adenovirus-based vaccine resulted in strong improvement of vaccine efficacy that was apparent by high control over FV-induced disease and correlated with improved $\mathrm{CD}^{+} \mathrm{T}$ cell responses and higher binding antibody titers. Similar findings were made when mice were immunized with adenovirus-based vectors encoding HIV proteins. No influence on vaccine efficacy was observed for co-administration of vectored IFN $\alpha 1$, IFN $\alpha 5$ and IFN $\beta$. Our results show that co-expression of specific type I IFN subtypes should be considered for adenovirus-based anti-retroviral vaccination.

\section{Methods}

\section{Cells and cell culture}

The human embryonic kidney cell line 293 (Microbix Biosystems, Toronto, ON, Canada), the human lung carcinoma cell line A549 (ATCC \# CCL-185) and the type I IFN indicator cell line MxRAGE7 ([20], Werner Müller, German Research Centre for Biotechnology, Braunschweig, Germany) were propagated in Dulbecco's modified Eagle medium (DMEM) with high glucose. A murine fibroblast cell line from Mus dunni [50] was maintained in RPMI medium (Invitrogen/Gibco, Karlsruhe, Germany). Cell culture media were supplemented with $10 \%$ heatinactivated fetal bovine serum (Invitrogen/Gibco) and $50 \mu \mathrm{g} / \mathrm{ml}$ gentamicin. Cell lines were maintained in a humidified $5 \% \mathrm{CO}_{2}$ atmosphere at $37^{\circ} \mathrm{C}(293, M$. dunni) or $32^{\circ} \mathrm{C}$ (MxRAGE7).

\section{Adenoviral vectors}

The adenoviral vectors Ad5.env, Ad5F35.env, Ad5.gag, and Ad5F35.gag [18] encode full-length F-MuLV Env or Gag proteins amplified by PCR from F-MuLV clone FB29 [51]; vectors were obtained using the AdEasy system and vectors pAdTrackCMV, pAdEasy-1, and pAdEasy-1/F35.

The adenoviral vector Ad5.Henv contains a codon-optimized full-length env based on HIV clade C isolate CN54 and was obtained using the AdEasy system after cloning of synthesized DNA into pShuttle-CMV plasmid. Ad5. Hgpsyn contains a codon-optimized HIV gag-pol based on the HIV clade B isolate BH10 that was described before [52] and was constructed using the AdEasy system and vectors pShuttle-CMV and pAdEasy-1.

The adenoviral vectors Ad5.Luc and Ad5F35.Luc encoding firefly luciferase have been described before $[53,54]$.

For the construction of type I IFN encoding adenoviral vectors, cDNAs for IFN $\alpha 1$, IFN $\alpha 2$, IFN $\alpha 4$, IFN $\alpha 5$, IFN $\alpha 6$, IFN $\alpha 9$ and IFN $\beta$ were subcloned from the plasmids pkCMVint.IFN $\alpha 1$, pkCMVint.IFN 2 2, pkCMVint. IFN $\alpha 4$, pkCMVint.IFN $\alpha 5$, pkCMVint.IFN $\alpha 6$, pkCMVint. IFN $\alpha 9$ [4] and pkCMVint.IFN $\beta$ [5] into pShuttle, recombinant Ad5 and Ad5F35 based vectors were obtained by homologous recombination of pShuttle constructs with pAdEasy- 1 and pAdEasy-1/F35, respectively, and transfection into 293 cells as described before [18]. 
All adenoviral vectors were purified with the Vivapure AdenoPACK 100 kit (Vivascience, Hannover, Germany). The adenovirus particle concentrations were determined by spectrophotometry as described previously [55] and expressed as viral particles (VP)/ml. The particle-to-PFU ratio of all vector preparations was $\sim 30: 1$.

Equal expression levels of IFNs by the recombinant adenovirus constructs were verified by a cell based bioassay using MxRAGE7 cells as described before [20]. Briefly, non-complementing A549 cells were transduced with type I IFN encoding adenoviral vectors at an MOI of 100 , culture supernatants were collected three days p.i. and added to subconfluent MxRAGE7 cells that were incubated for 2 days at $37^{\circ} \mathrm{C}$. Type I IFN induced GFP expression was analyzed by flow-cytometry.

\section{Mice}

Female CB6F1 hybrid mice (BALB/c $\times$ C57BL/6 F1; H$2^{\mathrm{b} / \mathrm{d}} \mathrm{Fv}^{\mathrm{b} / \mathrm{b}} \mathrm{Fv}^{\mathrm{r} / \mathrm{s}} \mathrm{Rfv}^{{ }^{\mathrm{r} / \mathrm{s}}}$ ) and female BALB/c mice were purchased from Charles River Laboratories (Sulzfeld, Germany). All mice were used when they were between 8 and 9 weeks of age and were treated in accordance with the regulations and guidelines of the institutional animal care and use committee of the Ruhr University Bochum, Germany.

\section{Immunization}

For immunization against FV, CB6F1 mice were immunized with Ad5 and Ad5F35-based vectors using a heterologous prime-boost immunization protocol with a 21-day interval. $1 \times 10^{9} \mathrm{VP}$ each of F-MuLV Env- and Gag-encoding vectors were mixed with either $1 \times 10^{9}$ VP of a type I IFN-encoding vector or a luciferaseencoding vector as a control and injected into both hind footpads in $100 \mu \mathrm{l}$ PBS. Ad5 vectors were used for the prime immunizations, and fiber-chimeric Ad5F35 vectors were used for boost immunizations.

In a control experiment, CB6F1 mice were immunized as described above with $1 \times 10^{9} \mathrm{VP}$ of type I IFNencoding vectors alone, using Ad5 vectors for prime and Ad5F35 vectors as boost immunizations.

To deplete $\mathrm{CD}_{4}^{+}$or $\mathrm{CD}^{+}$cells around the time of vaccination, mice were injected intraperitoneally with the antibodies 191.1 or 169.4 [56], respectively, on days $-3,-1$, $+1,+3$, and +5 around the day when the vaccine was applied. The depletion was performed when mice were prime- and boost-immunized.

For immunization against HIV, BALB/c mice were vaccinated with a single or a prime-boost immunization with Ad5-based vectors encoding HIV Env and Gag-Pol mixed with type I IFN- or luciferase-encoding vectors as described for vaccination against FV. When mice were boost immunized, Ad5-based HIV Env- and Gag-Pol- encoding vectors and Ad5F35-based type I IFN- or luciferase-encoding vectors were used.

\section{FV and challenge infection}

Uncloned, lactate dehydrogenase-elevating virus (LDV)free FV stock was obtained from BALB/c mouse spleen cell homogenate $(10 \%$, wt/vol) 14 days p.i. with a B-celltropic, polycythemia-inducing FV complex [57]. CB6F1 mice were challenged by the intravenous injection of 250 spleen focus-forming units. The course of disease was monitored twice a week by palpation of the spleen of each animal under general anesthesia. The spleen size was rated on a scale ranging from 1 (normal spleen size) to 4 (severe splenomegaly), as described previously [58].

\section{Viremia assay}

Ten days post challenge (p.c.), plasma samples from CB6F1 mice were obtained, and viremia was determined in a focal infectivity assay [59]. Serial dilutions of plasma were incubated with $M$. dunni cells for 3 days under standard tissue culture conditions. When cells reached $\sim 100 \%$ confluence, they were fixed with ethanol, labeled with F-MuLV Env-specific MAb 720 [60], and then with a horseradish peroxidase (HRP)-conjugated rabbit antimouse Ig antibody (Dako, Hamburg, Germany). The assay was developed using aminoethylcarbazole (SigmaAldrich, Deisenhofen, Germany) as substrate to detect foci. Foci were counted, and focus-forming units (FFU)/ ml plasma were calculated.

\section{Infectious center assay}

21 days p.c. FV-infected animals were sacrificed by cervical dislocation, the spleens were removed and weighed, and single-cell suspensions were prepared. Serial dilutions of isolated spleen cells were seeded onto M. dunni cells and incubated under standard tissue culture conditions for 3 days, fixed with ethanol, and stained as described for the viremia assay. Resulting foci were counted, and infectious centers (IC)/spleen were calculated.

\section{Binding antibody ELISA}

For the analysis of F-MuLV-binding antibodies, MaxiSorp ELISA plates (Nunc, Roskilde, Denmark) were coated with whole F-MuLV antigen $(5 \mu \mathrm{g} / \mathrm{ml})$, blocked with fetal calf serum, and incubated with serum dilutions. Binding antibodies were detected using a polyclonal rabbit-anti-mouse HRP-coupled anti-IgG antibody and the substrate tetramethylbenzidine (TMB+; both Dako Deutschland GmbH, Hamburg, Germany). Sera were considered positive if the optical density at $450 \mathrm{~nm}$ was 3 -fold higher than that obtained with sera from naïve mice. 


\section{Complement-dependent F-MuLV-neutralizing antibody assay}

To detect F-MuLV-neutralizing antibodies, serial dilutions of plasma in PBS were mixed with purified F-MuLV and guinea pig complement (Institut Virion/Serion $\mathrm{GmbH}$, Wuerzburg, Germany), incubated at $37^{\circ} \mathrm{C}$ for $60 \mathrm{~min}$, and then added to $M$. dunni cells that had been plated at a density of $7.5 \times 10^{3}$ cells per well in 24-well plates the day before. Seventy-two hours later cells were stained as described for the viremia assay. Dilutions that resulted in a reduction of foci by $50 \%$ or more were considered neutralizing.

\section{Tetramer staining of F-MuLV-specific T cells}

Spleens of CB6F1 mice were removed 3 days postchallenge (p.c.), and single-cell suspensions were prepared. For analysis of CD4 ${ }^{+} \mathrm{T}$ cells, spleen cells were stained with a phycoerythrin (PE)-coupled major histocompatibility complex (MHC) class II tetramer (containing the I-Ab-restricted F-MuLV Env epitope EPLTSLTPRCNTAWNRLKL [22]; kindly provided by the MHC Tetramer Core Facility of the National Institutes of Health, National Institute of Allergy and Infectious Disease, Atlanta, GA), peridinin chlorophyll protein (PerCP)-anti-CD4, and fluorescein isothiocyanate (FITC)-anti-CD11b (Becton Dickinson, Heidelberg, Germany). For detection of virus-specific $\mathrm{CD}^{+}$ $\mathrm{T}$ cells, spleen cells were stained with PE-coupled MHC I tetramer (containing the $\mathrm{H}-2 \mathrm{Db}$ restricted F-MuLV Gag-leader epitope AbuAbulLAbuLTVFL in which cysteine residues of the original amino acid sequence were replaced by amino-butyric acid to prevent disulfide bonding [21]), allophycocyanin (APC)anti-CD8 and FITC-anti-CD43. Data were acquired on a flow cytometer (FACSCalibur; Becton Dickinson, Mountain View, CA) and analyzed using CellQuest Pro (version 4.0.1; Becton Dickinson) and FlowJo (version 7.6; Tree Star, Ashland, OR) software.

\section{Flow-cytometric analysis of $\mathrm{T}$ cell induction}

To analyze the induction of $\mathrm{T}$ cells by the vaccine, mice were immunized once by footpad injection with Ad5.env and Ad5.gag vectors $\left(1 \times 10^{9} \mathrm{VP}\right.$ each $)$ and co-immunized with $1 \times 10^{9}$ VP Ad5.IFN 44 or Ad5.GFP as a control. Ten days later, the popliteal lymph nodes were isolated and lymph node cells were analyzed by flow cytometry. For analysis of the activation of $\mathrm{CD}^{+}$cells, we used the antibodies PE-anti-CD4 (Becton Dickinson), peridinin chlorophyll protein complex (PerCP)-anti-CD43 (BioLegend, Fell, Germany), phycoerythrin-cyanin-7 (Pe-Cy7)-antiCD62L (eBioscience, Frankfurt, Germany), APC-antiCD44 (Becton Dickinson) and eFluor450-anti-CCR7 (eBioscience). Data were acquired on an LSR II flow cytometer (Becton Dickinson) and analyzed using FlowJo software (Tree Star).

\section{Intracellular cytokine staining}

HIV-specific T cells were characterized by intracellular cytokine staining. Two weeks after immunization with vectors encoding HIV Env and Gag-Pol, spleens were removed and spleen cells were stimulated for $6 \mathrm{~h}$ in vitro with HIV Env- or Gag-derived peptides (IHIGPGRAFYT, gp120 309-320 [61], AMQMLKETI p24 $65-73$ [24]) or Gagderived peptides (SPEVIPMFSALSEGA, p24165-179, PVGEIYKRWIILGLN, p24 $257-271$ [25]; Metabion, Martinsried, Germany) representing described $\mathrm{CD}^{+}$and $\mathrm{CD}^{+} \mathrm{T}$ cell epitopes, respectively. Cells were stained with PE-anti-interferon gamma (IFN- $\gamma$ ), APC-anti-interleukin-2 (IL-2), FITC-anti-tumor necrosis factor alpha $(\mathrm{TNF}-\alpha)$ and either PerCP-anti-CD8 or PerCP-anti-CD4 (all from Becton Dickinson, Heidelberg, Germany) and analyzed by flow cytometry.

\section{Statistical analyses}

Statistical analyses were performed using the software SigmaStat 3.1 (Systat Software GmbH, Erkrath, Germany), testing with the Kruskal-Wallis one-way analysis of variance on ranks and Student-Newman-Keuls multiple comparison procedure.

\section{Additional material}

Additional file 1: Figure S1: Immunization schemes. This additional file provides schematic layouts of the experiments, indicating treatment and analysis schedules.

Additional file 2: Figure S2: Expression levels of type I interferons in Ad-infected DCs. The intrinsic expression levels of the tested type I interferons in DCs infected with Ad5.env were analyzed and compared to uninfected DCs.

\section{Acknowledgements}

We would like to thank Xiaolong Fan, Lund University, Lund, Sweden, for providing the plasmid pAdEasy-1/F35, and the NIH tetramer facility for providing the MHC II tetramers. This work was supported by the Deutsche Forschungsgemeinschaft (DFG grant GRK 1045 to KÜ, UD and OW).

\section{Author details}

${ }^{1}$ Department of Molecular and Medical Virology, Institute of Microbiology and Hygiene, Ruhr-University Bochum, Bldg. MA, Universitaetsstr. 150, D44801 Bochum, Germany. ${ }^{2}$ Institute of Virology, University Hospital Essen, University Duisburg-Essen, Robert-Koch-Bldg., Hufelandstr. 55, D-45122 Essen, Germany. ${ }^{3}$ Institute of Cell Biology (Cancer Research), Department of Molecular Cell Biology, University Hospital Essen, University Duisburg-Essen, Hufelandstr. 55, D-45122 Essen, Germany. ${ }^{4}$ Institute for Medical Microbiology and Hygiene, University Regensburg, Franz-Josef-Strauss-Allee 11, 93053 Regensburg, Germany. ${ }^{5}$ Department of Molecular Virology, Heinrich-PetteInstitute for Experimental Virology and Immunology, University Hamburg, Martinistr. 52, 20251 Hamburg, Germany. ${ }^{6}$ School of Veterinary and Biomedical Sciences, Murdoch University, South Street, Perth, 6150, WA Australia. ${ }^{7}$ Paul-Ehrlich-Institut, Division of Medical Biotechnology, PaulEhrlich-Str. 51-59, D-63225 Langen, Germany. 


\section{Authors' contributions}

WB constructed viral vectors encoding FV antigens, participated in the study design and drafted the manuscript. RL constructed viral vectors encoding IFNs and carried out the animal experiments. TO constructed viral vectors encoding IFNs. $L$ performed part of the animal experiments. MT performed flow cytometric analyses. GN produced and characterized the viral vectors encoding HIV antigens. SS participated in FV experiments. PG constructed viral vectors encoding HIV antigens. HW provided essential material for the study and revised the manuscript. CB provided essential material to conduct the study and revised the manuscript. KÜ participated in the study design. UD conceived the study, participated in its design, analyzed data, and wrote the manuscript. OW designed the study, generated some of the adenoviral IFN encoding vectors, analyzed data, and revised the manuscript. All authors read and approved the final manuscript.

\section{Competing interests}

The authors declare that they have no competing interests.

Received: 11 May 2011 Accepted: 26 September 2011

Published: 26 September 2011

\section{References}

1. Theofilopoulos AN, Baccala R, Beutler B, Kono DH: Type I interferons (alpha/beta) in immunity and autoimmunity. Annu Rev Immunol 2005, 23:307-336.

2. van Pesch V, Lanaya H, Renauld JC, Michiels T: Characterization of the murine alpha interferon gene family. J Virol 2004, 78:8219-8228.

3. Hibbert L, Foster GR: Human type I interferons differ greatly in their effects on the proliferation of primary B cells. J Interferon Cytokine Res 1999, 19:309-318.

4. Yeow WS, Lawson CM, Beilharz MW: Antiviral activities of individual murine IFN-alpha subtypes in vivo: intramuscular injection of IFN expression constructs reduces cytomegalovirus replication. I Immunol 1998, 160:2932-2939

5. Bartlett EJ, Cull VS, Mowe EN, Mansfield JP, James CM: Optimization of naked DNA delivery for interferon subtype immunotherapy in cytomegalovirus infection. Biol Proced Online 2003, 5:43-52.

6. Cull VS, Bartlett EJ, James CM: Type I interferon gene therapy protects against cytomegalovirus-induced myocarditis. Immunology 2002, 106:428-437.

7. Austin BA, James CM, Harle P, Carr DJ: Direct application of plasmid DNA containing type I interferon transgenes to vaginal mucosa inhibits HSV-2 mediated mortality. Biol Proced Online 2006, 8:55-62.

8. James CM, Abdad MY, Mansfield JP, Jacobsen HK, Vind AR, Stumbles PA, Bartlett EJ: Differential activities of alpha/beta IFN subtypes against influenza virus in vivo and enhancement of specific immune responses in DNA vaccinated mice expressing haemagglutinin and nucleoprotein. Vaccine 2007, 25:1856-1867.

9. Gerlach N, Gibbert K, Alter C, Nair S, Zelinskyy G, James CM, Dittmer U: Anti-retroviral effects of type I IFN subtypes in vivo. Eur J Immunol 2009, 39:136-146.

10. Ghany MG, Strader DB, Thomas DL, Seeff LB: Diagnosis, management, and treatment of hepatitis C: an update. Hepatology 2009, 49:1335-1374.

11. Wiegand J, van BF, Berg T: Management of chronic hepatitis B: status and challenges beyond treatment guidelines. Semin Liver Dis 2010, 30:361-377.

12. Cohen J: Public health. AIDS vaccine trial produces disappointment and confusion. Science 2003, 299:1290-1291.

13. Pitisuttithum P, Gilbert P, Gurwith M, Heyward W, Martin M, van GF, Hu D, Tappero JW, Choopanya K: Randomized, double-blind, placebo-controlled efficacy trial of a bivalent recombinant glycoprotein $120 \mathrm{HIV}-1$ vaccine among injection drug users in Bangkok, Thailand. J Infect Dis 2006, 194:1661-1671

14. Rerks-Ngarm S, Pitisuttithum P, Nitayaphan S, Kaewkungwal J, Chiu J, Paris R, Premsri N, Namwat C, de Souza M, Adams E, et al: Vaccination with ALVAC and AIDSVAX to prevent HIV-1 infection in Thailand. N Engl J Med 2009, 361:2209-2220

15. Dittmer $U$, Brooks DM, Hasenkrug KJ: Requirement for multiple lymphocyte subsets in protection by a live attenuated vaccine against retroviral infection. Nat Med 1999, 5:189-193.

16. Sun C, Zhang L, Zhang M, Liu Y, Zhong M, Ma X, Chen L: Induction of balance and breadth in the immune response is beneficial for the control of SIVmac239 replication in rhesus monkeys. J Infect 2010, 60:371-381.

17. Friend C: Cell-free transmission in adult Swiss mice of a disease having the character of a leukemia. J Exp Med 1957, 105:307-318.

18. Bayer W, Schimmer S, Hoffmann D, Dittmer U, Wildner O: Evaluation of the Friend Virus model for the development of improved adenovirusvectored anti-retroviral vaccination strategies. Vaccine 2008, 26:716-726.

19. Bayer W, Tenbusch M, Lietz R, Johrden L, Schimmer S, Uberla K, Dittmer U, Wildner O: Vaccination with an adenoviral vector that encodes and displays a retroviral antigen induces improved neutralizing antibody and CD4+ T-cell responses and confers enhanced protection. J Virol 2010, 84:1967-1976.

20. Bollati-Fogolin M, Muller W: Virus free, cell-based assay for the quantification of murine type I interferons. I Immunol Methods 2005, 306:169-175

21. Chen W, Qin H, Chesebro B, Cheever MA: Identification of a gag-encoded cytotoxic T-lymphocyte epitope from FBL-3 leukemia shared by Friend, Moloney, and Rauscher murine leukemia virus-induced tumors. J Virol 1996, 70:7773-7782.

22. Iwashiro M, Kondo T, Shimizu T, Yamagishi H, Takahashi K, Matsubayashi Y, Masuda T, Otaka A, Fujii N, Ishimoto A, et al: Multiplicity of virus-encoded helper T-cell epitopes expressed on FBL-3 tumor cells. J Virol 1993, 67:4533-4542.

23. Messer RJ, Dittmer U, Peterson KE, Hasenkrug KJ: Essential role for virusneutralizing antibodies in sterilizing immunity against Friend retrovirus infection. Proc Natl Acad Sci USA 2004, 101:12260-12265.

24. Doe B, Selby M, Barnett S, Baenziger J, Walker CM: Induction of cytotoxic T lymphocytes by intramuscular immunization with plasmid DNA is facilitated by bone marrow-derived cells. Proc Natl Acad Sci USA 1996, 93:8578-8583.

25. Trumpfheller C, Finke JS, Lopez CB, Moran TM, Moltedo B, Soares H, Huang Y, Schlesinger SJ, Park CG, Nussenzweig MC, et al: Intensified and protective CD4+ T cell immunity in mice with anti-dendritic cell HIV gag fusion antibody vaccine. J Exp Med 2006, 203:607-617.

26. Le Bon A, Durand V, Kamphuis E, Thompson C, Bulfone-Paus S, Rossmann C, Kalinke U, Tough DF: Direct stimulation of T cells by type I IFN enhances the CD8+ T cell response during cross-priming. J Immunol 2006, 176:4682-4689.

27. Cull VS, Broomfield S, Bartlett EJ, Brekalo NL, James CM: Coimmunisation with type I IFN genes enhances protective immunity against cytomegalovirus and myocarditis in gB DNA-vaccinated mice. Gene Ther 2002, 9:1369-1378.

28. Gehring S, Gregory SH, Kuzushita N, Wands JR: Type 1 interferon augments DNA-based vaccination against hepatitis $\mathrm{C}$ virus core protein. J Med Virol 2005, 75:249-257.

29. Kwissa M, Kroger A, Hauser H, Reimann J, Schirmbeck R: Cytokinefacilitated priming of CD8+ T cell responses by DNA vaccination. J Mol Med 2003, 81:91-101.

30. Leitner WW, Bergmann-Leitner ES, Hwang LN, Restifo NP: Type I Interferons are essential for the efficacy of replicase-based DNA vaccines. Vaccine 2006, 24:5110-5118.

31. Day SL, Ramshaw IA, Ramsay AJ, Ranasinghe C: Differential effects of the type I interferons alpha4, beta, and epsilon on antiviral activity and vaccine efficacy. J Immunol 2008, 180:7158-7166.

32. Faul EJ, Wanjalla CN, McGettigan JP, Schnell MJ: Interferon-beta expressed by a rabies virus-based HIV-1 vaccine vector serves as a molecular adjuvant and decreases pathogenicity. Virology 2008, 382:226-238.

33. Kumaki Y, Ennis J, Rahbar R, Turner JD, Wandersee MK, Smith AJ, Bailey KW, Vest ZG, Madsen JR, Li JK, et al: Single-dose intranasal administration with mDEF201 (adenovirus vectored mouse interferon-alpha) confers protection from mortality in a lethal SARS-CoV BALB/c mouse model. Antiviral Res 2011, 89:75-82.

34. Nair SR, Zelinskyy G, Schimmer S, Gerlach N, Kassiotis G, Dittmer U: Mechanisms of control of acute Friend virus infection by $\mathrm{CD} 4+\mathrm{T}$ helper cells and their functional impairment by regulatory T cells. J Gen Virol 2010, 91:440-451.

35. Iwanami N, Niwa A, Yasutomi Y, Tabata N, Miyazawa M: Role of natural killer cells in resistance against friend retrovirus-induced leukemia. J Virol 2001, 75:3152-3163.

36. Miyazawa M, Fujisawa R, Ishihara C, Takei YA, Shimizu T, Uenishi H, Yamagishi $H$, Kuribayashi $K$ : Immunization with a single T helper cell 
epitope abrogates Friend virus-induced early erythroid proliferation and prevents late leukemia development. J Immunol 1995, 155:748-758.

37. Dittmer U, Hasenkrug KJ: Different immunological requirements for protection against acute versus persistent Friend retrovirus infections. Virology 2000, 272:177-182.

38. Braun D, Caramalho I, Demengeot J: IFN-alpha/beta enhances BCRdependent B cell responses. Int Immunol 2002, 14:411-419.

39. Le Bon A, Schiavoni G, D'Agostino G, Gresser I, Belardelli F, Tough DF: Type I interferons potently enhance humoral immunity and can promote isotype switching by stimulating dendritic cells in vivo. Immunity 2001, 14:461-470.

40. Iwashiro M, Peterson K, Messer RJ, Stromnes IM, Hasenkrug KJ: CD4(+) T cells and gamma interferon in the long-term control of persistent friend retrovirus infection. J Virol 2001, 75:52-60.

41. Pike R, Filby A, Ploquin MJ, Eksmond U, Marques R, Antunes I, Hasenkrug K, Kassiotis G: Race between retroviral spread and CD4+ T-cell response determines the outcome of acute Friend virus infection. J Virol 2009, 83:11211-11222.

42. Pace L, Vitale S, Dettori B, Palombi C, La SV, Belardelli F, Proietti E, Doria G: APC activation by IFN-alpha decreases regulatory $T$ cell and enhances Th cell functions. J Immunol 2010, 184:5969-5979.

43. Havenar-Daughton C, Kolumam GA, Murali-Krishna K: Cutting Edge: The direct action of type I IFN on CD4 T cells is critical for sustaining clonal expansion in response to a viral but not a bacterial infection. I Immunol 2006, 176:3315-3319.

44. Marrack P, Kappler J, Mitchell T: Type I interferons keep activated T cells alive. J Exp Med 1999, 189:521-530

45. Miyazawa M, Nishio J, Chesebro B: Protection against Friend retrovirusinduced leukemia by recombinant vaccinia viruses expressing the gag gene. J Virol 1992, 66:4497-4507.

46. Huarte E, Larrea E, Hernandez-Alcoceba R, Alfaro C, Murillo O, Arina A, Tirapu I, Azpilicueta A, Hervas-Stubbs S, Bortolanza S, et al: Recombinant adenoviral vectors turn on the type I interferon system without inhibition of transgene expression and viral replication. Mol Ther 2006, 14:129-138.

47. Gibbert K, Dittmer U: Distinct antiviral activities of IFN-alpha subtypes. Immunotherapy 2011, 3:813-816.

48. Jaks E, Gavutis M, Uze G, Martal J, Piehler J: Differential receptor subunit affinities of type I interferons govern differential signal activation. J Mol Biol 2007, 366:525-539.

49. Zwarthoff EC, Mooren AT, Trapman J: Organization, structure and expression of murine interferon alpha genes. Nucleic Acids Res 1985, 13:791-804.

50. Lander MR, Chattopadhyay SK: A Mus dunni cell line that lacks sequences closely related to endogenous murine leukemia viruses and can be infected by ectropic, amphotropic, xenotropic, and mink cell focusforming viruses. J Virol 1984, 52:695-698.

51. Perryman S, Nishio J, Chesebro B: Complete nucleotide sequence of Friend murine leukemia virus, strain FB29. Nucleic Acids Res 1991, 19:6950.

52. Wagner R, Graf M, Bieler K, Wolf H, Grunwald T, Foley P, Uberla K: Revindependent expression of synthetic gag-pol genes of human immunodeficiency virus type 1 and simian immunodeficiency virus: implications for the safety of lentiviral vectors. Hum Gene Ther 2000, 11:2403-2413.

53. Dmitriev I, Krasnykh V, Miller CR, Wang M, Kashentseva E, Mikheeva G, Belousova N, Curiel DT: An adenovirus vector with genetically modified fibers demonstrates expanded tropism via utilization of a coxsackievirus and adenovirus receptor-independent cell entry mechanism. J Virol 1998, 72:9706-9713.

54. Hoffmann D, Bayer W, Heim A, Potthoff A, Nettelbeck DM, Wildner O: Evaluation of twenty-one human adenovirus types and one infectivityenhanced adenovirus for the treatment of malignant melanoma. J Invest Dermatol 2008, 128:988-998.

55. Mittereder N, March KL, Trapnell BC: Evaluation of the concentration and bioactivity of adenovirus vectors for gene therapy. J Virol 1996, 70:7498-7509

56. Cobbold SP, Jayasuriya A, Nash A, Prospero TD, Waldmann H: Therapy with monoclonal antibodies by elimination of T-cell subsets in vivo. Nature 1984, 312:548-551.
57. Chesebro B, Wehrly K, Stimpfling J: Host genetic control of recovery from Friend leukemia virus-induced splenomegaly: mapping of a gene within the major histocompatability complex. J Exp Med 1974, 140:1457-1467.

58. Hasenkrug K, Brooks DM, Robertson MN, Srinivas RV, Chesebro B: Immunoprotective determinants in friend murine leukemia virus envelope protein. Virology 1998, 248:66-73.

59. Sitbon M, Nishio J, Wehrly K, Lodmell D, Chesebro B: Use of a focal immunofluorescence assay on live cells for quantitation of retroviruses: distinction of host range classes in virus mixtures and biological cloning of dual-tropic murine leukemia viruses. Virology 1985, 141:110-118.

60. Robertson MN, Miyazawa M, Mori S, Caughey B, Evans LH, Hayes SF, Chesebro B: Production of monoclonal antibodies reactive with a denatured form of the Friend murine leukemia virus gp70 envelope protein: use in a focal infectivity assay, immunohistochemical studies, electron microscopy and western blotting. J Virol Methods 1991, 34:255-271.

61. Fomsgaard A, Nielsen HV, Bryder K, Nielsen C, Machuca R, Bruun L, Hansen J, Buus S: Improved humoral and cellular immune responses against the gp120 V3 loop of HIV-1 following genetic immunization with a chimeric DNA vaccine encoding the V3 inserted into the hepatitis B surface antigen. Scand J Immunol 1998, 47:289-295.

doi:10.1186/1742-4690-8-75

Cite this article as: Bayer et al:: Improved vaccine protection against retrovirus infection after co-administration of adenoviral vectors encoding viral antigens and type I interferon subtypes. Retrovirology $20118: 75$.

\section{Submit your next manuscript to BioMed Central and take full advantage of:}

- Convenient online submission

- Thorough peer review

- No space constraints or color figure charges

- Immediate publication on acceptance

- Inclusion in PubMed, CAS, Scopus and Google Scholar

- Research which is freely available for redistribution

Submit your manuscript at www.biomedcentral.com/submit 